\title{
ENERGIATUDATOSSÁGGAL KAPCSOLATOS ISMERETEK ÉS ÖSSZEFÜGGÉSEK VIZSGÁLATA
}

\begin{abstract}
Absztrakt
Írásom témája az energiatudatossággal kapcsolatos ismeretek és összefüggések vizsgálata egy miskolci középiskolában. A téma vizsgálata a XXI. században aktuális, és több megközelítésből is hasznos. A jövő generációinak az életvezetésébe már bele fog tartozni az energiatudatos viselkedés, szerencsés esetben az oktatás segítségével. Írásomban kitérek arra, hogy az emberiség az egyik legnagyobb ajándékot akkor adja az utódainak, ha a környezeti nevelést egyre magasabb szintre emeli. Már a jelenben érezhető a hatása, mivel a gyerekek befolyásolni tudják a szüleiket. Az ismeretek és összefüggések vizsgálatát Miskolcon, a Herman Ottó Gimnáziumban, kilencedikes diákoknál végeztem el. Kérdőíves módszert választottam: két időpontban történt a kitöltés, a kettő között pedig a témához szorosan kapcsolódó előadásokat tartottam. A tanulóközpontú előadások összeállítása során felhasználtam az elsőként kitöltött kérdőív tapasztalatait és eredményeit.

A felmérés megállapításai közé tartozik, hogy senki nem állította a kérdőívet kitöltők közül, hogy az emberek már energiatudatosak; valamint a diákok többségében azt válaszolták, hogy nem foglalkoznak sokat ezzel a témával az iskolában. A két kérdőív kitöltése közötti előadások egyik legfontosabb eredménye - a második kérdőív alapján - az, hogy több diáknál szóba került otthon az energiatudatos életvitel. Azon kérdések esetében pedig, amelyekben korábban a diákok többsége nem látott összefüggést, az előadások után megértették azokat. Ez megerősíti a tárgy oktatásának fontosságát. Kiderült az is, hogy a nemek és korosztályok tekintetében eltérő attitűdváltozás történik ugyanazon előadásokon való részvétel következményeképpen. Ez azt jelenti, hogy az eltérő nemü és csak kismértékben eltérö korosztályú diákokat máshogyan kell megszólítanunk, ha eredményeket szeretnénk elérni az energiatudatossággal kapcsolatban.
\end{abstract}

Kulcsszavak: energiatudatosság; környezeti nevelés; tanulóközpontúság 


\section{Bevezetés}

Meggyőződésem, hogy a kultúra és a nevelés szoros kapcsolatban áll egymással. Megfelelő neveléssel mai életvitelünkhöz az energiatudatos viselkedés hozzákapcsolható. A fejlett országokban élő, nem teljesen elszegényedett rétegeknek pedig már a kultúrájához is hozzá kell, hogy tartozzon. A legszegényebb rétegektől, úgy vélem, nem várhatjuk el, hogy energiatudatosan viselkedjenek, hiszen a szegénység olyan hatással is lehet rájuk, amelynek következtében ezt a viselkedést hátrébb sorolják más, az élethez fontosabb dolgoknál. Főleg ha azt tapasztalják, hogy a tőlük jelentősen gazdagabb rétegek tagjai sem cselekednek energiatudatosan. Ha kezdetben nem is, de az élethosszig tartó tanulás mellett elköteleződött személy az idő múlásával látni fogja az összefüggéseket, és nagyobb valószínűséggel az energiatudatos viselkedés híve lesz. A társadalom, a nemzet és az ország számára is fontos, hogy az egyénekből felépülő közösség ökotudatos legyen.

Kozma Tamás szerint az ökoszisztéma kihívásai és a rá adott válaszok összekötik a közösséget. Az embernek kettős kötöttsége van: a közösséghez és az ökoszisztémához. A közösségre jellemző beállítódások és viselkedésminták a faj- és önfenntartást szolgálják. A közösség céljai átörökítéssel értékrenddé válnak, így alakulnak ki a normák és az értékek. (Kozma, 2001)

\section{A nevelés és az energiatudatosság kapcsolatáról}

\subsection{Pozitív példa}

Sok nevelési irányzat és nevelési gyakorlat létezik. Ezeknek az ismerete előnyős, hiszen így egy egyén vagy egy intézmény optimálisan alakíthatja ki neveléselméleti koncepcióját és gyakorlatát. Általánosan a nevelés értékközvetítés vagy értékteremtés, természetesen a nevelést meghatározza a cél is. A nevelési cél nem más, mint értékek és normák rendszere. Egy eszményként megfogalmazott pszichés diszpozíció, melynél a nevelő célja az, hogy ezt a lehető legtökéletesebben megvalósítsa a növendék (Korn, 2003).

A jelenlegi életvitelünkön mindenképpen változtatnunk kell, hiszen a következménye az lett, hogy olyan folyamatok indultak el, amelyek visszafordításának vagy megállításának elmaradása súlyos következményeket idézhet elő. Amennyiben ezek a változtatások nem következnek be, ha nem is katasztrófák, de olyan új életkörülmények alakulnak ki, amilyenekkel az emberiség még nem találkozott. A cél elérése, hogy a Föld számunkra és a velünk itt létező élőlények számára is tovább élhető legyen, nem lehetetlen. Pozitív példa lehet a montreali és a kiotói egyezmény, melyekben több ország is vállalta az ózonréteget 
romboló kémiai anyagok kibocsátásának csökkentését. Az egyezmények változásokat idéztek elö, melyeknek hatására az ózonréteg pusztulása lelassult. A hasonló eredmények elérésében segíthetnek az újabb egyezmények, jegyzőkönyvek és megállapodások.

\subsection{A szociális életképesség}

Ahhoz, hogy az energiatudatos viselkedés mint szokásszerủ belső szükséglet, illetve mint jellemző magatartásforma megjelenjen egy egyénnél, elengedhetetlen a megfelelő szociális életképességek megléte. A szociális életképesség megfelelő megalapozásának hosszú távon számos előnye van. Az egyén tehermentesíti a társadalmat, képes önállóan ellátni magát, magának megteremteni azokat a feltételeket, amelyek a létfenntartásához elengedhetetlenek. A cél az, hogy az optimális iskola elvégzése után az egyénben mint szokásszerủség, mint belső szükséglet jelenjenek meg azok a magatartásformák, amelyek a társadalom számára hasznosak és elfogadottak. A szociális életképesség kialakításában az iskolának kitüntetett szerepe van, hiszen a neveléssel-oktatással felkészítik a tanulót a munka világára; az élethosszig tartó tanulásra és az egészség fenntartására, az egészséges életmódra. Az optimális iskola megfelelően felkészít a szociális életképességre, készségekre és ezen felkészítés mindenki számára egyaránt elérhető kell hogy legyen (Bábosik, 1999).

\section{Az energiatudatosság szoros kapcsolatai}

\subsection{Kapcsolat a tudománnyal}

A neveléstan a neveléstudomány egyik részdiszciplínája. Tematikája az idők változásával bővül, bővülni kényszerül (Horvát és Palotai, 2000). A fejlődési tendenciákat követni kell, és a napi aktualitásoknak is meg kell felelni, hiszen számos, korral nem haladó dolgunk már nem lesz sikeres, versenyképes, vagy elfogadhatatlan lesz a jövőben. Tapasztalhatjuk, hogy az újabb és újabb tankönyvekbe egyre aktuálisabban kerülnek be a modern technikával kapcsolatos ismeretek, feladatok, hiszen akár a mai napon is felfedezhetnek valamit, ami a jövőben már természetes lesz. Fontos, hogy lapozgassuk, nézegessük a régebbi tankönyveket is, hiszen felfedezhetjük a fejlődésnek és változásnak a tantárgyra gyakorolt hatását.

\subsection{Az egyik legfontosabb bizonyíték, hogy az energiatudatosságra nevelés elenged- hetetlenül fontossá vált}

Vannak, akik szerint nem is az ember a hibás a világban lezajlódó globális változásokért, és vannak olyan vélemények is, melyek szerint minek ilyen kérdésekkel foglalkozni, hiszen a mi generációnk már úgysem éri meg a következményeket. 
Amennyiben kíváncsiak vagyunk, hogy valóban az ember tevékenysége miatt történtek-e ezen változások, akkor a teljes Föld éghajlatait szimuláló modellek számításaira kell hagyatkoznunk. Ezek a tömeg, az energia és az impulzus megmaradását leíró parciális differenciálegyenleteken alapuló modellszámítások. Ezen modellszámítások eredménye alapján a kérdésünkre 95\%-os valószínűséggel állíthatjuk, hogy igen. Pontosabban megfogalmazva 95\%-os a valószínűsége, hogy a 20. század közepétől kezdődő felmelegedés feléért az ember a felelős. Amikor a természetes és antropogén hatást betápláljuk a számítógépes modellekbe, akkor ezekkel a modellekkel reprodukálni tudjuk az elmúlt száz esztendő történéseit. Azonban amikor az antropogén tényezőket kivesszük a modellekből, akkor az utóbbi ötven esztendő melegedése egyáltalán nem mutatható ki. Ennek következtében szinte biztosra mondhatjuk, hogy az ember felelős a változásokért. A kijelentés csak azért nem lehet 100\%-os, mert kettő hibát elkövethetünk, aminek a szakértők 5\%-nál kisebb esélyt adnak. Ezt a csekélynek mondható számot az Éghajlatváltozási Kormányközi Testület szakértői becsülték meg. A hiba közül az egyik, amit elkövethetnek, hogy túlbecsülik az üvegházhatású gázok szerepét, és az valójában sokkal kisebb a számítottnál. A másik hiba, amit elkövethetnek, hogy valami olyan dolog okozza a változást, amiről még nem vettek tudomást (Mika, 2007).

A technikai fejlődés három területen mérhető, ezek az energia felhasználása, az irányítástechnika és az informatika. Mindhárom területen óriási fejlődés mutatkozik, és előreláthatólag ez a jövőben is folytatódni fog.

Tapasztalhatjuk, hogy diákok és szülők is sokat panaszkodnak arra, hogy nagyon sok a fölösleges tanulnivaló, nagy a mennyisége, és az a véleményük, hogy az életben sohasem fogják használni a tanultakat. Az energiatudatossághoz kapcsolódó órákra, foglalkozásokra ez nem igaz, továbbá a technikai fejlődés modellje is bizonyítja, hogy szükség van a minél több információra. A pedagógusok feladata, hogy az óriási információmenynyiségben segítsenek a diákoknak megtalálni a pontos és megfelelő adatokat.

\subsection{Néhány érdekes adat Magyarország energiafelhasználásáról}

Az energiával való foglalkozás, az energiatudatosság és az ezzel kapcsolatos oktatás fontosságát azokból az adatokból is felismerhetjük, amelyeket a Magyarországra vonatkozó - 2018. augusztus 10-én nyilvánosságra hozott - primer energiamérleg tartalmaz. Figyelemreméltó adat, hogy hazánkban 1990 óta 2018-ban volt a legmagasabb - 39672 millió $\mathrm{kWh}$ - az egy naptári évben történő belföldi villamosenergia-felhasználás ( $K S H$, 2018). Ezek alapján meggyőződésem, hogy változtatnunk kell, és új célokat szükséges megfogalmaznunk annak érdekében, hogy ugyanannyi vagy több energiát fel tudjunk 
használni anélkül, hogy a környezetet károsítanánk. Ki kell jelentenünk, hogy egyre inkább változtatnunk kell az életvitelünkön, és egyre fontosabb, hogy megjelenjen az oktatásban az energiatudatosság.

\subsection{A feszültségekről}

Veenhoven szerint „az elmozdulás a fenntartható fogyasztás irányába némi csökkenést eredményez az észlelt boldogságban, legalábbis átmenetileg, de elég boldogan tudunk élni luxusfogyasztás nélkül is" (Veenhoven, 2004, 39. o.). Véleményem szerint vannak olyan emberek a jóléti államokban, akik ezt nem így fogják gondolni, vagy mindenféleképpen nehezen élik majd meg. Ezt arra alapozva állítom, hogy a környezetszennyezésre is szinte a legvégső határokig képes lett volna az emberiség egy olyan általa létrehozott életvitel miatt, amely még számára sem egészséges, csak kényelmes. A kérdőív által is bebizonyosodott, hogy a diákok a kényelmet az utazásuk alkalmával sokkal többre értékelik, mit a sportot vagy az egészséget.

\subsection{A fenntarthatóság a Nemzeti alaptantervben}

A Nemzeti alaptanterv a nevelési célok között említi a fenntarthatóságot és környezettudatosságot, valamint az alapvető törekvést arra, hogy a tanulók megismerjék azokat a társadalmi és gazdasági folyamatokat, amelyek változásokat, válságokat idézhetnek elő (NAT, 2012). Fontos, hogy az átlagemberek, a diákok megismerjék azt, hogy amennyiben beleavatkozunk azokba a folyamatokba, amelyek a természetben vagy a környezeti tényezők rendszerében zajlanak, azok előbb-utóbb ránk is hatással lesznek.

\subsection{Az ökológiai lábnyom, a fenntarthatóság és a környezeti nevelés}

Magyarország lakosainak átlagos ökológiai lábnyoma 5 hektár/fó, a biológiai kapacitása viszont csak 3 hektár/fó, vagyis jelenlegi életvitelünk fenntartásához az ország területének másfélszeresére lenne szükség (Schróth, 2004).

Az ENSZ a Millenniumi Fejlesztési Célokban (2000) nyolc célkitűzést rögzített a 20002015 közötti időszakra. A 2016-2030 közötti időszakra kitűzött tizenhét fenntartható fejlődési cél arra enged következtetni, hogy az előző nyolc célt nem sikerült teljes mértékben megvalósítani (Mika, 2017).

Andris Piebalgs, aki az Európai Bizottság energiaügyi biztosa volt a 2004 és 2010 közötti időszakban, korábban fizika szakos tanárként és iskolaigazgatóként is dolgozott. Tapasztalatai alapján úgy vélte, hogy a gyerekek képesek befolyásolni a családjukat és általában a felnőtteket is. Ezért is lettek kulcsfontosságúak az energiafelhasználással kapcsolatos tudatosság fokozására vonatkozó oktatási kezdeményezések (Európai Bizottság, 2006). 


\section{Az energiatudatosságról szóló előadások előzményéről}

Az előadásokat a Miskolci Herman Ottó Gimnáziumban tartottam meg, Takács Zoltán matematika-fizika szakos tanár úrral egyeztetve. A gimnáziumban épp Herman-hét volt, és a környezetvédelem volt a téma, amibe nagyszerủen illettek az energiatudatossággal kapcsolatos előadások.

\section{Kedvenc tantárgy}
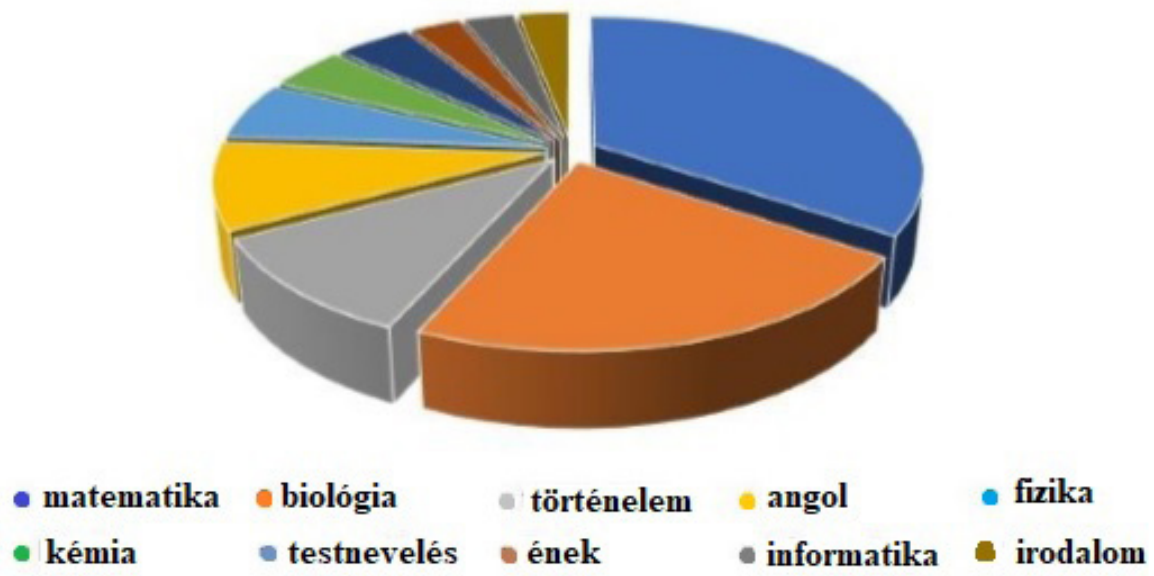

1. ábra: A kérdőívet kitöltők kedvenc tantárgyainak aránya

\subsection{A kedvenc tantárgyak megoszlása}

Tanulóközpontú hozzáállás helyett választhattam volna az eredményközpontúságot vagy a tudásközpontúságot. Ám a célom nem ez volt, ezért - az előzetes tervekkel ellentétben -elvetettem bárminemű jutalmat vagy más egyéb, a kérdőív eredményeit befolyásoló tényezőt. A diákok teljesen szabadon dönthettek a válaszok megadásánál. Egyetlenegy szempontot vettem figyelembe, azt, hogy mely kérdésre jött a legtöbb rossz válasz. Ennek tudatában igyekeztem azt a területet fókuszba állítani (részletezni, magyarázni), és az eredmények javulását a kérdőívben ott várni. Ezek a fütéssel és szigeteléssel kapcsolatos ismeretek voltak, melyek szoros összefüggést mutatnak a káros anyag kibocsátásának csökkentésével. Amennyiben minden háztartás csak a szigetelést megoldaná, ami gazdaságilag biztos hasznot hozna számukra, már az is óriási lépés lenne az emberiségnek a környezet károsításának mérséklésében. Egy másik szempont az, hogy a szigeteléseknek a terjedésével csökken a fosszilis energiafelhasználás, és ez nemcsak 
a károsanyag-kibocsátás csökkenését eredményezi, hanem az ország importfüggősége is csökkenne. A harmadik oldalról megközelítve az energiafelhasználás csökkenése létrehoz egy olyan új állapotot, amelyben az energiafelhasználást biztosító berendezéseket ki lehet cserélni új, korszerűbb és kisebb teljesítménnyel üzemelőkre. Ezekkel a lépésekkel a beruházásaink megtérülésének idejét is lerövidíthetjük.

Az iskola sajnos mindenkor ki van téve annak a veszélynek, hogy a tantárgyak vagy a társadalom funkcionális elvárásai miatt háttérbe szorul a tanulóközpontúság. Ám az iskolát legitimáló törvények és más dokumentumok tiltják ezt, és elóírják a tanulóközpontúságot. A tanulóközpontúságot az iskolák nevelési feladatainak a leírása tartalmazza (Korn, 2006). Ennek megfelelően egy olyan előadást szerettem volna összeállítani, amely alkalmazkodik a gyerekek érdeklődéséhez. Próbáltam a tantárgyak közötti integrációt is hangsúlyozni. Célom az volt, hogy megtörjem az iskolai monotonitást, hogy maradandó élményt nyújtsak a tanulóknak. Reméltem, hogy az élményt másokkal, otthon is megosztják. Meggyőződésem, hogy 45 perc energiatudatosságról szóló előadás akkor ér el nagyobb hatást, ha kapcsolódik a tanulók érdeklődési köreihez. Ezért az előadást a tanulók kedvenc tantárgyaihoz kapcsoltam. Figyelembe vettem az osztály fejlettségi szintjét, előismereteit, illetve a szemléltető eszközt is ennek megfelelően választottam ki.

Kedvenc tantárgyhoz kapcsolódó részek (1. ábra), elhangzott energiatudatossághoz kapcsolódó információk

\subsubsection{Matematika}

A 9. osztályban tanult függvényelemzéshez - ordináta és abszcissza tengelyek - kapcsolódott a Herman Ottó Gimnázium földgázfogyasztásának elemzése június 1-től a következő év június 1-ig. Ez egy másodfokú függvényhez hasonlít, melyet eltolunk az x és y tengelyen is pozitív irányba. Mivel a függvényünk fordított, ezért mínusz előjelűnek kell lennie.

Az előadás közben a gyerekek nagy része egyértelmủ jelét adta, hogy érti, miről van szó, és össze tudták kapcsolni az ábrán látottakat a tanultakkal. Az épületek szigetelésével kapcsolatos megtakarítást pénzben is kifejeztük egy egyszerủ számítással.

\subsubsection{Angol}

Azok számára, akiknek a kedvenc tantárgya az angol, a táblázatokban, ahol eredetileg is angolul voltak az adatok, meghagytam azt angol nyelven. Így együtt fordítottunk le közösen az energiatermeléssel kapcsolatos szavakat, többek között a coal, nuclear renewables, naturalgas, petroleum, other liquids, World energy consumption, by energy source kifejezéseket. Továbbá az Energiagazdálkodás szakújság legújabb számában külön érdekes szavak találhatók, és a témához kapcsolódnak. 


\subsubsection{Adalékok további tantárgyakhoz}

Az előadások elején a Vad Fruttik nevü zenekar egyik koncertjéből néztünk egy rövid részletet, a Tartalak című dalból, ahol a zenekar énekese felveszi a telefonjával a közönséget, és a közönség szinte minden tagja szintén rögzíti a koncertet. Később ezeket a felvételeket egy helyen összegezték, és abból készítettek videóklipet. A dal meghallgatására az előadás elején akkor került sor, amikor az emberiséget érő változásokról beszéltünk. Szinte kijelenthető, hogy mivel már mindenki rendelkezik képek, filmek és hangok rögzítésére alkalmas, megfelelő minőségủ eszközzel, ez az a pillanat, amikor a kameraman foglalkozása feleslegessé válik. Ilyen pillanatok voltak már a történelemben, foglalkozások szűntek meg, és keletkeztek újak.

A biológia tantárgyhoz kapcsolódóan az állattartás és a megújuló energiaforrásokra való átváltás előnyei kerültek szóba. Például az Egyesült Királyságban található Crocadon Farmon (Halwell) a napelemekkel borított területet komplexen használják fel állattartással egybekötve.

A fizika tantárgyon belül a hőmennyiség tananyaghoz (nyolcadikos, kilencedikes tananyag) kapcsolódtunk, amikor a szigeteléssel kapcsolatos hőmennyiség-csökkenéseket elemeztük a diagramon.

A földrajz tantárgyat senki nem választotta, így amikor a beérkező gázvezetékről néztünk térképet, mely Ukrajnán át Oroszországból érkezik, érdemesebb volt az oroszukrán konfliktusról beszélni a történelem tantárgy kapcsán, mely sajnos ránk is hatással lehet.

A kémia tantárgyhoz kapcsolódóan az óceánokban lezajló változásokat említettük: a savasodás jelen esetben azt jelenti, hogy kevésbé lesz lúgos a víz.

A testnevelést kedvenc tantárgyként írók számára szóba került a maratoni futás, melynél az volt a hasonlat, hogy ha elindulunk egy ilyen hosszú távon, nem szerencsés, ha a szervezetünk tartalékát már a verseny elején kimerítjük.

$\mathrm{Az}$ informatika iránt érdeklődő diákok számára elmondtam, hogyan készítettem az előadáson bemutatott grafikonokat Excel programmal.

Az irodalomkedvelőkkel József Attila Indiában, hol éjjel a vadak... címủ versét hallgattuk meg, majd megbeszéltük, hogy milyen kapcsolat van a vers és az emberiség energiafelhasználása között.

\section{Tapasztalatok}

Falus Iván szerint a jó kutatót a problémaérzékenység, az igazán termékeny kérdések felismerésének a képessége jellemzi. (Falus, 2003) 


\subsection{Az előadások tapasztalatai}

Figyeltem a diákokat, és körülbelül 20 perc elteltével, amikor már érzékeltem, hogy az előadás nem mindenki figyelmét köti le, a monotonitás megtörése céljából egy napelemes mozgásérzékelővel ellátott lámpát vettem elő, melyet szemléltetés céljából az előadásra vittem.

A szemléltetés (demonstráció, illusztráció) egy olyan szemléletes oktatási módszer, amelynek során a tanulmányozandó tárgyak, jelenségek, folyamatok észlelése, elemzése megtörténik. Ez az egyik legősibb oktatási módszer, a szenzualizmus pedagógiája, mely a valóságból való kiindulást tekintette az ismeretszerzés egyetlen hatékony útjának (Falus, 2003).

A valósággal való szembesülés valóban nem, vagy legalábbis nagyon nehezen helyettesíthető a diákok számára jobb módszerrel. Igyekeztem valamilyen problémafelvetéssel egybekötni a hatékonyság érdekében, emellett a demonstráció eredményességének a feltételei rendelkezésre álltak. Problémafelvetéssel volt kapcsolatos, hogy egy kert vagy egy ingatlan olyan részére is el lehet helyezni egy ilyen napelemes lámpát, ahová nehéz vagy körülményes áramot vezetnünk. Természetesen a lényegkiemelésnél a takarékos megoldásra és az energiatudatosságra hívtam fel a figyelmet.

Az energiatudatosságról szóló előadás vagy óra továbbfejleszthető, nagyon sok megközelítés lehetséges. Naponta jelennek meg olyan írások, cikkek, ötletek, amelyekben azt szemléltetik, miként lehetünk takarékosabbak. Ezek leginkább az egyén eredményeit méltatják, és nem térnek ki arra, hogy sok aprónak tűnő ötlettel is nagy eredményeket lehet elérni.

Az előadások közben is érdemes a reakciókat figyelnünk, nyitott szemmel járnunk, és tapasztalatokat szereznünk, ahogy Earl Babbie is írja: „összefüggéseket fedezzünk fel a megfigyelt dolgokban és értelmezzük azokat” (Babbie, 2008).

\subsection{A kérdőív}

A kérdőív tartalmaz egy nominális skálát, amely az elemzésnél elengedhetetlen (F/L). Egy egyértelmü kategorizálást, ahogy a diák meghatározza, hogy hány éves (14-16), továbbá tartalmaz egy intervallum- és arányskálát (1-5). Függő változó: attitűdmérés, az arányskálából (1-5).

A kutatás érvényes és aktuális, az energiatudatossággal kapcsolatos attitűddel összefüggésben felvetődött kérdésekre keresi a választ. Objektív, mert mérhető számokat tartalmaz, de mint minden vizsgálat, sérülékeny. A diákok diverzitása és mennyisége elegendő lehet az általánosításra és a válaszok megadására, ám számos körülmény van, ami befolyásolhatja a kutatást. A kutatás nem veszi figyelembe a tanár személyét, hiszen a diákok attitűdjét maga a tanár személye is befolyásolhatja, aki a kérdőív kitöltésénél jelen van, vagy aki az előadást tartja. Továbbá nem tudhatjuk, hogy a válaszadó 
mennyire őszinte. Egy időpillanatban történik, ami nem feltételezi, hogy egy másik pillanatban már más véleménye lehet.

\section{A kérdőívek kiértékelése}

A kérdőív gyakorlatilag tét nélküli volt, a diákok saját maguk, egyénileg dönthettek a válaszokról. 67 fö töltötte ki, 29 lány és 38 fiú.

Az 1-5 intervallumskálán megjelölhették, hogy szerintük mennyire fontos az energiatudatosság. Két szakirodalom alapján is azt feltételeztem, hogy a lányok által megjelölt szám magasabb lesz. Kónya György A nem és településtipus befolyása a környezeti attitüdre címü munkájában arra a következtetésre jutott, hogy az iskolai környezeti nevelésben alkalmazott módszereknél nem tesznek különbséget a nemek között. Pedig a fiúk környezeti attitűdje gyengébb, ezért érdemes lenne megvizsgálni, milyen módszerekkel lehetne az érzelmi hozzáállásukat, viselkedésüket javítani (Kónya, 2018). Egy Jordániában elvégzett másik kutatásban, melyben az iskolai tanulók tudását és hozzáállását vizsgálták a megújuló energiákkal kapcsolatban, az az eredmény született, hogy a lányok jobban ismerik a megújuló energiákkal kapcsolatos dolgokat, mint a fiúk (Zyadin, Puhakka, Ahponen, Cronberg és Pelkonen, 2012).

Az első kérdőívnél, melyet a 2. ábra szemléltet, és a később kitöltött kérdőívnél is, a lányok által megjelölt számok átlaga nagyobb lett, vagyis a feltételezésemnek megfelelőek az adatok.

\section{Energiatudatosság attitűd}

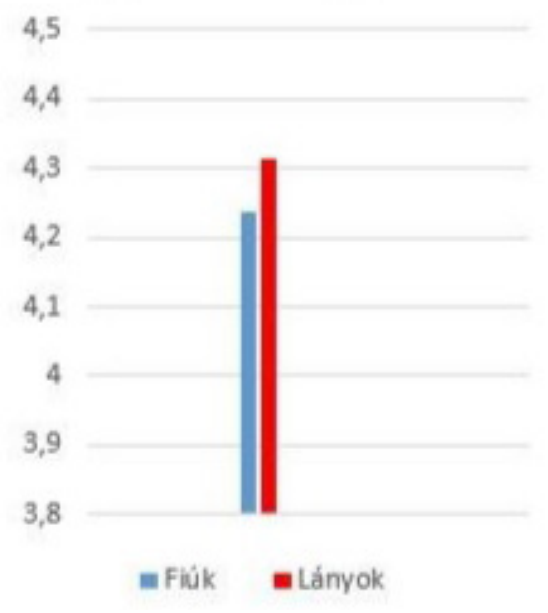

2. ábra: A nemek közötti attitűdkülönbség 
A következő feladatban szavakat kellett fontossági sorrendbe rakniuk a diákoknak (3. ábra). Mondhatjuk, hogy mind az öt szóhoz pozitív érzelem kapcsolódik, illetve a gazdagság szó kelthet vegyes érzelmeket. Nem véletlen, hogy az utolsó helyre sorolták a diákok. A legfontosabbnak a békét tartották, a második pedig a tanulás lett. Az egyetértés és az energiatudatosság holtversenyben a harmadik helyre került. Amennyiben az előző kérdéshez viszonyítva itt is nemek szerint vizsgáljuk a válaszokat, megállapíthatjuk, hogy a lányoknál itt is fontosabbnak bizonyult az energiatudatosság, mint a fiúknál.

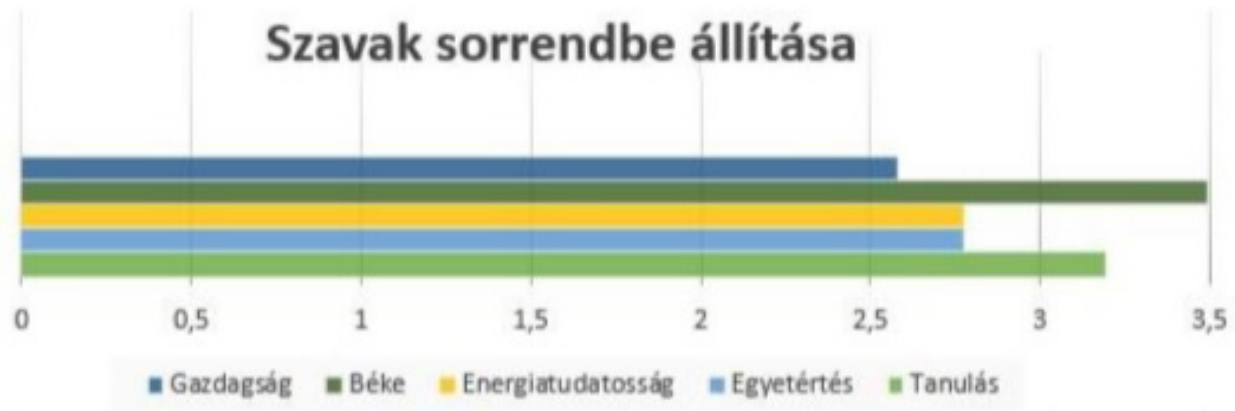

3. ábra: Szavak sorrendbe állítása

Azt, hogy az energiatudatos életvitel függ-e az anyagi jóléttől, nehéz megítélni, hiszen van olyan mértékű szegénység, ahol már nem fontos más, csak az életben maradás egyik napról a másikra. A súlyos anyagi deprivációt úgy állapíthatjuk meg, ha a deprivációs indikátor közül legalább négy jellemző az adott személyre. A szegények nagyon sok hátrányt szenvednek el, a diákok szerint nem várható el tőlük az energiatudatos viselkedés. A kilenc indikátor között jelenik meg az is, ha valaki nem tudja megfelelően füteni a lakását. A diákok többsége úgy gondolja, hogy az anyagi jóléttől függ az energiatudatos viselkedés.

Érdekes válaszokat eredményezett, hogy melyik közlekedési eszközt kedvelik a legjobban a diákok (4. ábra). Mindössze egy fó választotta a vonatot. Az autó után a bicikli következett, ami optimizmusra ad okot. A választás után egy gyerek kivételével mindenki írt pár sort, megindokolva, hogy miért ezt a közlekedési eszközt választotta. Ezekben az indokokban 22 alkalommal szerepel a kényelmes és 18 alkalommal a gyors szó. Az olcsó és az egészséges szó egyszer, míg a sport szó ötször került említésre. Ezekből a szavakból egyértelműen következtethetünk arra, hogy a fiatalok a közlekedési eszközöknél milyen tulajdonságokat részesítenek előnyben. 


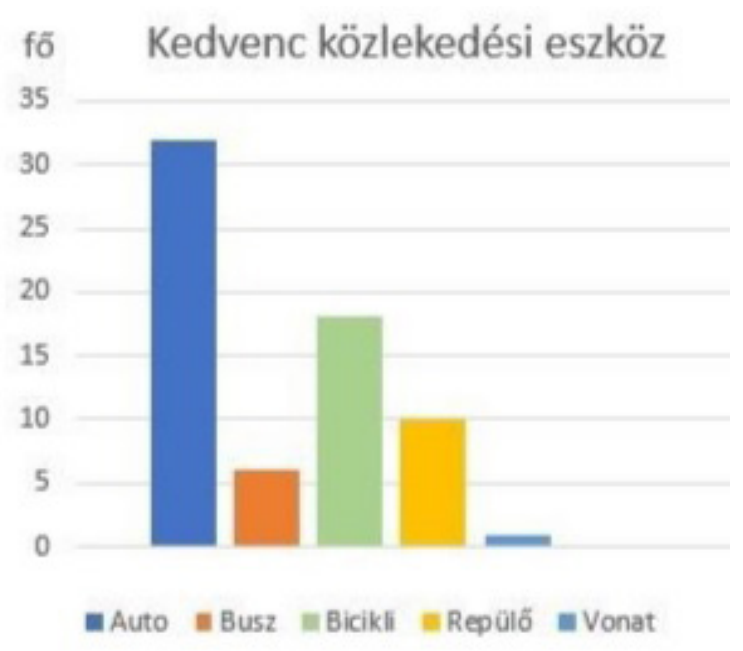

\section{4. ábra: A diákok által megjelölt kedvenc közlekedési eszközök aránya}

A következő két kérdésre adott válaszokat együtt szeretném elemezni. Az, hogy valaki mitől lenne energiatudatosabb, és ő mit gondol, mitől változnának meg az emberek ebben a kérdésben pozitív irányba, egészen mást mutat (5-6. ábra). A próbakérdőív után azt gondoltam, hogy nem egymás után teszem fel a két kérdést, hiszen akkor fennáll annak a veszélye, hogy valaki automatikusan válaszol. A kérdések között lévő más kérdések hagynak időt, hogy a kitöltő ne kapcsolja össze tudatosan a két kérdést. Egyértelmű választ kaptam arra, hogy az emberiség és az ember saját maga megítélése nem ugyanaz ebben a kérdésben, ebből következik, hogy más kérdésekben sem lehet az. Továbbá kiderül, hogy a diákok többségben azt állítják saját magukról, hogy ők akkor változtatnának, ha az emberiség érdeke azt kívánja (5. ábra). Mivel az emberiség érdeke azt kívánja, egyértelműen gondolhatjuk azt, hogy az energiatudatos viselkedést és a jelenlegi környezetkárositó életvitelünkön való változtatást úgy érhetjük el, ha elmagyarázzuk, megtanítjuk a diákoknak azt, hogy jelenleg a bolygónk milyen állapotban van, és ha nem változtatunk, milyen irányba fog haladni a jövőben. Senki sem gondolta azt a 67 diákból, hogy az emberek energiatudatosan viselkednek. Leginkább abban látják a változtatás esélyét, ha jutalmat kapnának érte. A második helyre a büntetést tették, ebböl az következik, hogy ők is érzik, valamivel motiválni kell és lehet is jobb irányba az embereket. A második helyen van az a megállapítás, hogy „energiatudatos vagyok”. Az szintén optimizmusra ad okot, hogy míg az emberiséget úgy ítélik meg, hogy csak jutalom ellenében tudnának leginkább változni, csak mindössze 7 fő várna el jutalmat cserébe a változtatásáért. Nagyon kevés, aki büntetés miatt változna, és a legkevesebben mondták azt, hogy ők semmitől sem változtatnának. 


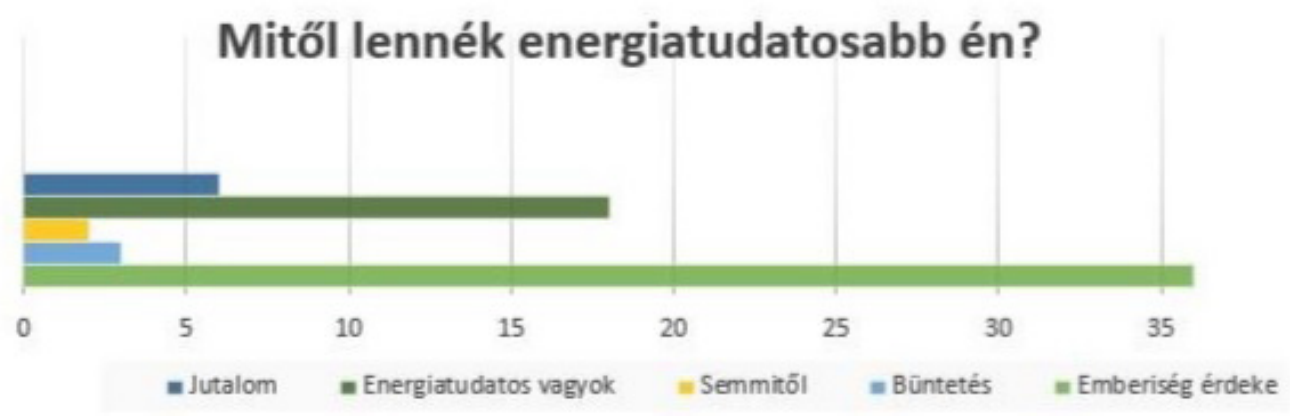

5. ábra: A mitől lennék én energiatudatosabb kérdésre adott válaszok aránya

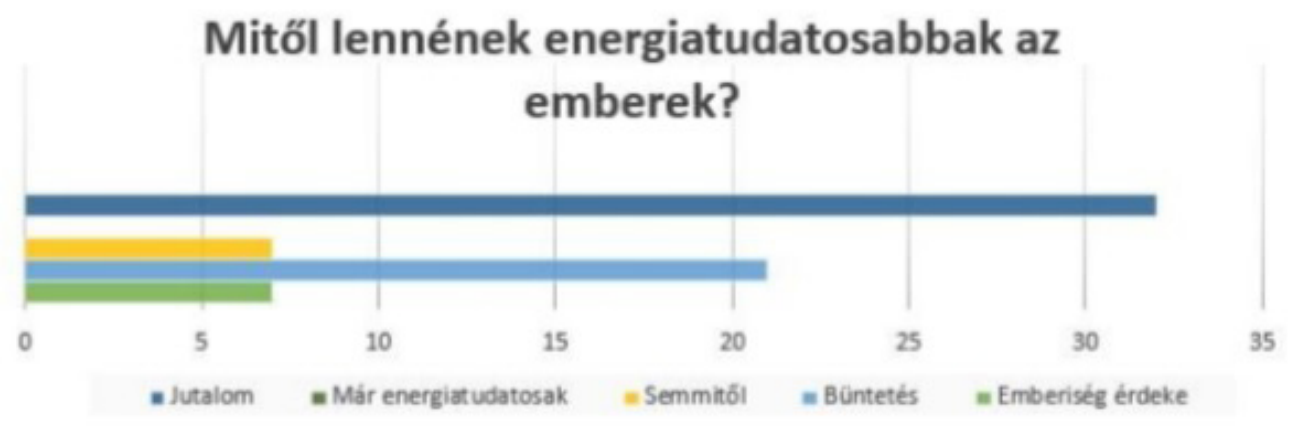

6. ábra: A mitől lennének az emberek energiatudatosabbak kérdésre adott válaszok aránya

A szigeteléssel kapcsolatos kérdésnél egyértelmüen kiderült, hogy a gyerekek nagy többsége nem ismerte az összefüggést, hogy azzal a káros anyag kibocsátását csökkenteni lehet. 67 válaszadóból 42 fó volt az, aki a „nem tudom” és a „helytelen” válaszokat jelölte meg. Az előadás után egy héttel ismételten feltett kérdésre már a 42 diák kétharmada helyes válaszokat adott.

A Statistical Package for Social Science(SPSS) programmal három adathalmazt elemeztem kétféleképpen összehasonlítva. Az egyik az életkor és az energiatudatosság fontossága, a másik a tanulmányi átlag és az energiatudatosság fontossága közötti kapcsolat. Az életkornál feltételeztem, hogy körülbelül mindenki 15 éves. A diákok választhattak, hogy 14, 15, 16 évesnek mondják magukat, mit gondolnak, mennyinek érzik magukat. Tapasztalatom alapján az utóbbi években kijelenthető, hogy az óvodában visszatartásnak a hatására már elég nagy azoknak a létszáma az iskolában, akik 6 évesnél idősebb korukban kezdték az első osztályt, ezért az évfolyamból, amire járnak, nem következtethetünk 
egyértelmüen az életkorukra. A tanulmányi átlagukat is ők határozták meg, oda azt írhatták be, amennyi a félévi átlaguk volt.

Az SPSS segítségével megállapítható, hogy az életkor és az energiatudatosság fontossága közötti Pearson-korreláció értéke 0,096, ami azt jelenti, hogy gyenge a kapcsolat. Amennyiben 0,05 alatt lenne az érték, az szignifikáns különbséget eredményezne, akkor mondhatnánk, hogy erős a kapcsolat. Ám a 0,096-os kapott érték a Pearson-korrelációnál csak $\mathrm{p}=0,439$ szinten eredményez szignifikáns különbséget, vagyis az életkor nem határozza meg jelentősen az energiatudatosság fontosságára adott válaszszámokat.

A másik elemzésnél, a tanulmányi átlag és az energiatudatosság fontossága közötti kapcsolatnál a korreláció értéke 0,321 . Ez az érték $\mathrm{p}=0,008$ valószínűségi szinten eredményez szignifikáns különbséget, mivel ez az érték kisebb, mint 0,05, ezért kijelenthetö, hogy a kapcsolat szignifikáns, vagyis a tanulmányi átlag erősen meghatározza az energiatudatosság fontosságára adott érték nagyságát.

\section{Konklúzió}

A kérdőív elvégzése után azt állapítottam meg, hogy mindenféleképpen hasznos és érdemes az energiatudatos neveléssel foglalkozni. A nevelés hatásának következtében történhetnek olyan változások az emberek életvitelében és így a világban, amelyek megakadályozhatják a nagymértékü környezetkárosítást.

\section{Energiatudatosság attitűd}

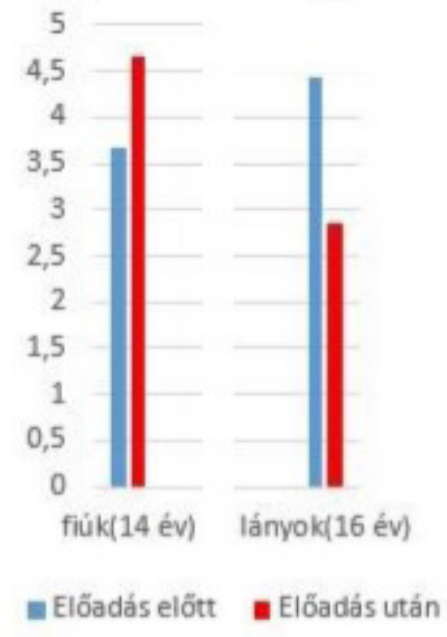

7. ábra: Az előadás előtti és utáni attitűd felmérésének részletes összehasonlítása 
Igyekeztem tanulóközpontú előadást összeállítani az előzőekben felmért kedvenc tantárgyak alapján. A jövőben olyan részeket is érdemes az előadásokon megemlíteni, amelyek kifejezetten a lányok számára érdekes témákról szólnak (7. ábra).

Meggyőző bizonyítéknak tekinthetjük azt, hogy senki nem mondta a kérdőívet kitöltők közül, hogy az emberek már energiatudatosak, és a diákok maguk is többségében azokat a válaszokat jelölték meg, hogy nem foglalkoznak sokat ezzel a témával az iskolában. A 67 megkérdezett diákból csak 21 fö mondta azt, hogy többségében eleget foglalkoznak az energiatudatossággal.

A két legfontosabb pozitívuma az előadásoknak és a vizsgálatnak, hogy több diák is a fiatalabbak közül azt a választ jelölte meg, hogy az előadás következtében volt szó otthon az energiatudatos életvitelről. Ezenkívül amire a legtöbb „helytelen” vagy „nem tudom” válasz érkezett, az azt bizonyította, hogy többségében nem látják az összefüggést a szigetelt házak számának növekedése és a károsanyag-kibocsátás csökkenése között. Az előadás után egy héttel kitöltött kérdőívben már egyértelműen kiderült, hogy ezt az összefüggést többségében megértették. Már akkor is nagy mennyiségű energiát és ezzel kapcsolatban rengeteg káros anyag kibocsátását takaríthatnánk meg, ha minden ember elvégeztetne a házán olyan szigetelési munkát, amilyet anyagi értelemben megengedhet magának.

Véleményem szerint a témával érdemes foglalkozni, kutatni a jövőben, hasonló kérdőíveket nagyobb létszámú résztvevők bevonásával elemezni. Világunk folyton változik, ezért mindig naprakésznek kell lenniük a pedagógusoknak, hogy mely témákban érhető el pozitív hatás a neveléssel.

\section{Irodalom}

Babbie, E. (1996/2008). A társadalomtudományi kutatás gyakorlata. Balassi Kiadó, Budapest.

Bábosik I. (1999). A nevelés elmélete és gyakorlata. Nemzeti Tankönyvkiadó, Budapest. Európai Bizottság (2006). Energiaoktatás - A holnap energiafogyasztóinak tanitása, Energiaügyi és Közlekedési Föigazgatóság. Letöltés: https://docplayer.hu/810005-Energiaoktatas-a-holnap-energiafogyasztoinak-tanitasa-europai-bizottsag-energiaugyi-es-kozlekedesi-foigazgatosag.html, (2019. 04. 02.)

Falus I. (2003). Didaktika. Nemzeti Tankönyvkiadó, Budapest.

Hankiss E. (2005). Az ezerarcú én. Osiris Kiadó, Budapest.

Horváth L. és Palotai Ferencné (2000). Neveléstan. Bessenyei György Könyvkiadó, Nyíregyháza. 
Kónya Gy. (2018). A nem és a településtípus befolyása a környezeti attitüdre. Journal of Applied Technical and Educational Sciences, 8(3), 29-42.

Korn, F. W. (2003). Pedagógia. Osiris Kiadó, Budapest.

Kozma T. (2001). Bevezetés a nevelésszociológiába. Nemzeti Tankönyvkiadó, Budapest.

KSH (2018). Táblák (Stadat) - Idősoros éves adatok - Energiagazdálkodás, Letöltés: http://www.ksh.hu/stadat_eves_3_8. (2019.04.02.)

Mika J. (2017). Education in the Sustainability Development Goals (2016-2030), sustainability in the education. Journal of Applied Technical and Educational Sciences, 7(4).

NAT (2012). A Nemzeti Alaptanterv kiadásáról, bevezetéséről és alkalmazásáról szóló 110/2012. (VI. 4.) Kormányrendelet. Magyar Közlöny, 66, 10635-10848, Budapest. Schróth Á. (szerk.) (2004). Környezeti nevelés a középiskolában. Trefort Kiadó, Budapest.

Veenhoven, R. (2004). Sustainable consumption and happiness. Erasmus University Rotterdam Letöltés: https://mpra.ub.unimuenchen.de/11279/1/MPRA_paper_11279. $\operatorname{pdf}$ (2019. 04.02.)

Zyadin, A., Puhakka A., Ahponen P., Cronberg, T., Pelkonen, P. (2012). Renewable Energy 45, 78-85. https://doi.org/10.1016/j.renene.2012.02.002

Név: Csáki Szabolcs

Munkahely: Szerencs ZRT.

Beosztás/foglalkozás: energetikus

e-mail: energiatudatossag@freemail.hu

Szakmai bemutatkozás: A Nyíregyházi Egyetemen mesterképzésben fizika szakos tanári, a Budapesti Műszaki és Gazdaságtudományi Egyetemen energiagazdálkodási szakmérnök, az Eszterházy Károly Egyetemen okleveles neveléstudomány szakos bölcsész végzettséget szereztem. Pedagógusként általános iskolában, középiskolában és felnőttoktatásban tettem szert tapasztalatokra. Jelenleg energetikusként dolgozom. 